\title{
"humanidades
}

Revista Humanidades

ISSN: 2215-3934

humanidades@ucr.ac.cr

Universidad de Costa Rica

Costa Rica

\section{Con el corazón en el papel. Historia y teoría de las cartas de amor}

Rovira Gordillo, Maria

Con el corazón en el papel. Historia y teoría de las cartas de amor

Revista Humanidades, vol. 12, núm. 1, e48442, 2022

Universidad de Costa Rica, Costa Rica

Disponible en: https://www.redalyc.org/articulo.oa?id=498068490003

DOl: https://doi.org/10.15517/h.v12i1.48442

\section{(c) (1) (8)}

Esta obra está bajo una Licencia Creative Commons Atribución-NoComercial-SinDerivar 3.0 Internacional. 


\section{Con el corazón en el papel. Historia y teoría de las cartas de amor}

Amb el cor al paper. Història i teoria de les cartes d'amor

Maria Rovira Gordillo

Universitat Autònoma de Barcelona, Barcelona, España

maria.rovirag@e-campus.uab.cat

DOI: https://doi.org/10.15517/h.v12i1.48442

Redalyc: https://www.redalyc.org/articulo.oa? id $=498068490003$

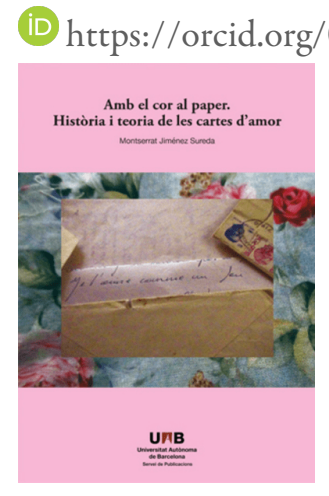

Jiménez Sureda Montserrat. Amb el cor al paper. Història i teoria de les cartes d'amor. 2020. España. Universitat Autònoma de Barcelona. 525pp.. 978-84-490-9322-7

La autora del libro que nos ocupa, Montserrat Jiménez Sureda, ha sido docente en la Venice International University y, en la actualidad, es profesora de Historia y Género en la Universitat Autònoma de Barcelona. El tema de Amb el cor al paper. História i teoria de les cartes d'amor (2020) es nuevo para la historiadora, pues sus anteriores trabajos se han centrado, por un lado, en el estudio de la historia y la historiografía de la Iglesia, con obras como L'Església catalana sota la monarquia dels Borbons. La catedral de Girona en el segle XVIII (1999); La memória de pedra. Les lápides sepulcrals del pla de la catedral de Girona (2005); o Crist i la história. Els inicis de la historiografia eclesiàstica catalana en el seu context europeu (2014); por otro lado, Jiménez Sureda también ha sido fructífera en el ámbito de los análisis de género y la historia de las mujeres, con libros como Les bruixes. Del feminicidi històric a la icona social (2017) y Les dones i les professions sanitàries al llarg de la bistória (2017).

$\mathrm{Al}$ inicio de Amb el cor al paper. História i teoria de les cartes d'amor, Montserrat Jiménez Sureda recuerda que el amor es un proceso fisiológico con un alto contenido emocional y reitera varias veces que, debido a la naturalidad de este sentimiento, las personas hemos tendido a expresarlo necesariamente a lo largo de nuestra existencia con los mecanismos que se encuentran a nuestra disposición. Así, desde la Antigüedad, en las épocas donde la comunicación era más pausada y las distancias físicas suponían grandes impedimentos para las relaciones de todo tipo, cuando cartearse era tan natural como hablar, la estima era transmitida por carta. Todo aquel que sabía escribir era susceptible de expresar, por medio de la epístola, su amor.

Como nos recuerda la autora, el suyo no es un ensayo sobre la historiografía de las cartas de amor. Al iniciar esta investigación, su voluntad fue la de conocer un poco más el espíritu humano. Mediante la exploración de la bibliografía sobre el tema epistolar, la lectura de fuentes primarias de archivos catalanes, y extensas reflexiones personales que se desarrollan a lo largo del libro, la historiadora consigue su objetivo.

De esta forma, Jiménez Sureda conciencia a sus lectores sobre la importancia del estudio de la epistología dentro de la disciplina histórica, esto es, destacar el influyente rol protagonizado por las epístolas en la historia. Las cartas que expresan amor permiten recrear la vida privada de emisores y receptores, entender sus razones y sentimientos, y son uno de los pocos documentos del pasado con los cuales gran parte de la humanidad se puede sentir identificada: en mayor o menor medida, todos hemos sentido amor por quienes nos rodean. 
Aún así, hasta la década de 1960, y, en ocasiones, hasta nuestra actualidad, parte de la historiografía ha marginado de manera consciente el mundo de las emociones, considerándolo subjetivo e irracional. Por ende, documentos como las cartas de amor, que subliman los sentimientos, han sido poco considerados por la academia.

No obstante, como bien muestra Jiménez Sureda a lo largo de su ensayo, aunque la disciplina histórica haya denostado la epistología, esta rama de investigación enriquece las aproximaciones antropológicas a la globalidad del ser humano. Por ello, no sería superfluo decir que el estudio de la epístola de amor en la historia puede ser el correcto camino hacia una historia de las emociones y la intimidad de las personas, claramente influida por los estudios culturales de la historiografía que dejan de lado las grandes estructuras y teorías explicativas para centrarse en lo concreto, en este caso, los sentimientos de amor expresados literariamente.

Debido a su naturaleza sentimental, las cartas de amor son eminentemente emotivas, pero también racionales, pues su emisor emplea sus capacidades cognitivas para conseguir seducir o hacer llegar un determinado mensaje al receptor con su prosa. De esta forma, devienen un mecanismo para dar forma a la historia de las emociones. Además, las epístolas amorosas nos pueden ayudar a situar a las personas que las escribían dentro de los paradigmas y el contexto cultural en el cual se adscribían. Un ejemplo de esta dinámica es bien recogido por Jiménez Sureda cuando asevera que gran parte de las cartas amorosas de la Europa occidental han reflejado, a lo largo de su historia, pautas provenientes del cristianismo sociológico imperante.

Estas dinámicas son expuestas en los 103 capítulos de Amb el cor al paper. História $i$ teoria de les cartes d'amor. Cada uno, breve, y sin más conexión con el resto que el tema de fondo, analiza algún aspecto determinante de la evolución histórica en las epístolas de amor, plantea teorías comunicativas que emanan de ellas, o expone ejemplos de las cartas que la autora ha reinterpretado. Esta suerte de presentación formal es idónea, puesto que la constitución de apartados tan fugaces permite tanto introducir multitud de temáticas diferentes como agilizar y simplificar la lectura, y que clarifica los conceptos básicos en los cuales se centra el libro.

A parte de la multiplicidad de temáticas que abarca este ensayo, cabe destacar otros puntos fuertes de la obra. En primer lugar, es interesante el planteamiento novedoso de la autora. Por una parte, como ella misma expone, es muy complicado ser exhaustiva, puesto que la cantidad de epístolas, sobre todo de época contemporánea, es ingente, así como la bibliografía que trata la temática. También explicita que no es su intención albergar todo el conocimiento, cosa imposible. No se trata de un texto de historiografía sobre las cartas de amor, sino de relacionar lecturas, teorías y conclusiones concernientes a la temática. Tampoco la selección de lecturas y los apartados inscritos en este análisis son ortodoxamente académicos: la autora es consciente de esta característica, pero defiende que es ella quien escoge qué y cómo aparece en su libro. De manera que nos encontramos delante una síntesis muy personal sobre la historia y la metodología de estudio de las cartas de amor, hecho que confiere originalidad a la obra.

Por otra parte, a esta singularidad se le suma un aspecto poco corriente en los textos académicos: Jiménez Sureda nos permite acceder a sus reflexiones, experiencias, valoraciones y aportaciones personales que, entre corchetes, integra en el texto, lo que enriquece y humaniza el estudio y acerca al lector y a la escritora. A esto se le suma el acierto comunicativo de emplear un lenguaje ágil, vivo, el cual permite una lectura amena; con localismos que enriquecen el relato y nos acercan a la personalidad de la historiadora. Sin duda, este empleo del lenguaje por parte de la autora encaja perfectamente con la temática principal de la obra, puesto que se aproxima al lector de manera mimética a un tema tan íntimo y rodeado de misterio como el que encierran las cartas de amor. A medida que Jiménez Sureda se abre paso por las epístolas, ella hace lo propio consigo misma.

En segundo lugar, también es interesante la particularidad de la propia temática. Si bien es cierto que, en la actualidad, el interés por el estudio de la epistología ha crecido substancialmente, Jiménez Sureda consigue introducir en su estudio el análisis de la pluma de dos grandes colectivos olvidados por la historia: las mujeres y las criaturas. La autora manifiesta repetidamente que los epistolarios más tradicionales suelen ser androcéntricos y adultistas, convirtiendo tanto féminas como niños y niñas solo en destinatarios o 
proyecciones de las diatribas de hombres adultos. De suerte que la autora trata de integrar en su ensayo algunos capítulos concernientes a ambos, con el fin de que devengan protagonistas y no solo como figurantes de sus historias de amor, como sujetos pasivos, receptores, de la acción del hombre.

En tercer lugar, consideramos que esta obra abre nuevas vías de investigación dando voz a los que no han tenido. La autora afirma en varias ocasiones que algunas de las limitaciones de su libro son, por una parte, las cuestiones geográficas, ya que la obra se centra en ejemplos eminentemente occidentales, y, por otra parte, lo concerniente a las minorías culturales, puesto que, por ejemplo, colectivos como los gitanos, han sido excluidos de sus análisis. Pero este hecho no tiene porqué ser considerado un defecto: Jiménez Sureda propone una metodología que puede ayudar a emprender estudios de esta índole sobre otras culturas, territorios diversos, y conjuntos de personas hasta la fecha marginados por la disciplina histórica.

Con todo, y estando de acuerdo en que las epístolas son una herramienta fundamental a la hora de reconstruir la historia de las emociones, vale la pena tener en cuenta que el estudio de las cartas presenta cuatro limitaciones. En primera instancia, los textos analizados no dejan de ser la plasmación escrita de sentimientos muy sublimados, de manera que no nos encontramos delante de la realidad, sino de una determinada percepción de esta. En segunda instancia, hasta la generalización de la escolarización, gran parte de la población era analfabeta. Por ende, quien escribía cartas era una minoría privilegiada de hombres ricos (cultural y monetariamente). En muchos casos la correspondencia de infantes, mujeres y pobres no ha sido conservada.

En tercera instancia, cabe destacar que en una epístola el historiador o la historiadora no puede percatarse de la gestualidad o las expresiones. Al tener en cuenta el hecho de que la mayor parte de la comunicación entre humanos no se construye con palabras, quien analiza epistolarios concluye que contienen gran parte de subjetividad. Al final, el investigador descifra el código que compartieron emisor y receptor desde su presente y bajo sus paradigmas. Y, por último, tenemos que pensar en el hecho que las clases sociales que habían generado documentación escrita actualmente han accedido a ella. Gran parte de la población puede ser autora de un epistolario. Por esta razón no se puede ser exhaustivo con las cartas contemporáneas: la cantidad de información es inmensa. Este hecho plantea el problema de cómo vamos a gestionar la sobreinformación los historiadores del futuro.

En definitiva, a pesar del reto que significa sintetizar una temática tan amplia y con una metodología de trabajo novedosa, Montserrat Jiménez Sureda concibe una obra que, más que un ensayo, es un diálogo, una suerte de carta entre la emisora y los receptores y las receptoras, de tono cercano y personal. Una obra que, aunque trata uno de los temas más representados e investigados por las artes y las humanidades, como es el amor, logra presentarlo de forma original.

\section{REFERENCIAS}

Jiménez, M. (2020). Amb el cor al paper. História i teoria de les cartes d'amor. Universitat Autònoma de Barcelona. 